\title{
Inter-pregnancy folate and iron status of women in an inner-city population
}

\author{
Wendy Doyle $^{1 *}$, Aparna Srivastava ${ }^{2}$, Michael A. Crawford ${ }^{1}$, \\ Rupinda Bhatti ${ }^{3}$, Zoé Brooke ${ }^{1}$ and Kate L. Costeloe ${ }^{2}$ \\ ${ }^{1}$ Institute of Brain Chemistry \& Human Nutrition, University of North London, London N7 8DB, UK \\ ${ }^{2}$ Department of Child Health, St Bartholomew's and the Royal London School of Medicine and Dentistry ECIA 7BE, UK \\ ${ }^{3}$ Haematology Department, Homerton Hospital, London E9 6SR, UK
}

(Received 10 August 2000 - Revised 29 January 2001 - Accepted 28 February 2001)

\begin{abstract}
The purpose of the present study was to evaluate whether micronutrient supplementation improved the nutritional status of women with poor diets during the inter-pregnancy interval. Fifty-five women who had given birth to a low birth weight baby $(<2.5 \mathrm{~kg})$, and who planned to have a further pregnancy, were recruited to a prospective randomised study in East London, UK. Of the fifty-five mothers recruited, forty-four $(78 \%)$ met fewer than four of sixteen dietary reference values according to the information provided in a $7 \mathrm{~d}$ diet diary, and were categorised as having an 'inadequate' diet. Half of the mothers in the 'inadequate'-diet group were randomly assigned to receive a micronutrient and a single cell oil supplement containing docosahexaenoic acid. All participants received dietary advice based on analysis of their diet diaries, and general lifestyle advice on preparing for pregnancy. Mothers had a blood sample taken at 3 and 9 months post-partum to measure their folate, Fe stores and fatty acid status. Mean serum and erythrocyte folate levels increased significantly between 3 and 9 months post-partum in both the adequate-diet group and the supplemented group. At 9 months post-partum, over half of the unsupplemented, inadequate-diet group remained severely deficient in folate (serum folate $<230 \mathrm{nmol} / \mathrm{l})$ and had low serum ferritin levels $(<15 \mu \mathrm{g} / \mathrm{l})$. The high prevalence of inadequate diets in this inner-city population and the low motivation of women to participate in a nutrition programme suggests that consideration should be given to the provision of free folate and Fe supplements to all women in this and similar populations, or at least to women who have delivered a low birth weight baby, who plan further pregnancies.
\end{abstract}

Folic acid: Iron: Pregnancy interval: Low birth weight

It is widely accepted that maternal nutrition before and during the first trimester of pregnancy is important in relation to birth weight (Doyle et al. 1990; Scholl et al. 1997) and to birth defects (Wald et al. 1991; Czeizel, 1993; Shaw \& Lammer, 1995). However, little is known about maternal post-delivery micronutrient status, and if deficiencies are present, how long it takes to restore maternal nutrient stores. Women who have previously had a low birth weight baby are at increased risk of doing so again (Raine et al. 1994). Both prematurity and intra-uterine growth retardation may be partly due to poor maternal nutrition but the relative importance of individual nutrients and the importance of non-nutritional factors are likely to differ.

These observations prompted us to investigate the feasibility of developing programmes of nutrition counselling targeting women who have already delivered a baby weighing $<2.5 \mathrm{~kg}$ at birth, with the aim of restoring their nutrient status in the inter-pregnancy interval.

A pilot study on nutrition counselling was undertaken in Hackney, London, where the incidence of low birth weight is among the highest (9.7\% of live births) in England and Wales (Office of National Statistics, 1998). In that study, forty-one women who had previously had a low birth weight baby and had been shown to have poor dietary intakes were exposed to 6 months intensive nutrition counselling, but failed to improve their nutritional intake. The results led us to conclude that nutrition counselling per se in the inter-pregnancy interval did not significantly improve the nutritional intake of many women in this socially disadvantaged population (Doyle et al. 1999).

\footnotetext{
* Corresponding author: Dr Wendy Doyle, fax + 44 (0)1727 844249, email wendydoyle@bda.uk.com
} 
The purpose of the present study is to evaluate the feasibility of using a broad spectrum multivitamin-mineral and a docosahexaenoic acid supplement as an adjunct to nutrition counselling during the inter-pregnancy interval in women shown to have an inadequate diet, who have delivered a low birth weight baby, and plan a further pregnancy at some time in the future.

The principal markers of nutritional status chosen were folate and docosahexaenoic acid status, both of which correlate well with supplemented intake (Blonk et al. 1990; Cuskelly et al. 1996), and Fe which we have previously found to be poor in girls from this population during puberty (Doyle et al. 1994). This paper reports the effects upon overall diet and upon folate and Fe status. Fatty acid status will be reported separately.

\section{Methods}

Approval to undertake this study was obtained from the East London and City Health Authority Local Research Ethics Committee. Recruitment of mothers commenced in June 1997 and ended in March 1998; mothers who had had a low birth weight baby $(<2500 \mathrm{~g})$ at the Homerton Hospital, London, were approached by the research dietitian while still in hospital. The study was fully explained to the mother and informed signed consent was sought prior to participation in the study.

Criteria for exclusion from the study included women who had had a stillbirth or neonatal death, who were already taking a dietary supplement or who were unable to speak English. Those who had diabetes, sickle cell disease or chronic medical problems, such as essential hypertension and thyroid disease, or who were known to be HIV-positive were also excluded.

Eight weeks after the birth of their baby, mothers were asked to visit the Mother and Baby Clinic, a drop-in clinic for women wanting dietary advice relating to pregnancy, sited in the centre of Hackney, London. They were given $£ 10$ for each visit to the clinic to cover travel expenses and as a gesture for the inconvenience caused. They were asked to keep a $7 \mathrm{~d}$ diet diary, analysis of which was used to categorise mothers into an 'inadequate' - or an 'adequate' diet group. The energy and nutrient content of their diets, as described in their diet dairies, were calculated using FOODBASE $^{\circledR}$ (Institute of Brain Chemistry \& Human Nutrition, University of North London, London N7 8DB, UK), a nutritional analysis program based on McCance and Widdowson's The Composition of Foods (Paul \& Southgate, 1991), with enhanced fatty acid data produced by the Institute of Brain Chemistry and Human Nutrition, London.

An 'inadequate' diet was arbitrarily defined as one which was assessed as meeting fewer than four of sixteen dietary reference values (Department of Health, 1991), calculated from $7 \mathrm{~d}$ diet diaries recorded by mothers at the outset of the study. The sixteen dietary reference values considered were: energy, protein, $\mathrm{Fe}, \mathrm{Ca}, \mathrm{Mg}, \mathrm{Zn}, \mathrm{I}, \mathrm{Cu}$, vitamin $\mathrm{A}$, thiamin, riboflavin, niacin, vitamin $\mathrm{B}_{6}$, vitamin $\mathrm{B}_{12}$, folic acid and vitamin $C$. Using shuffled envelopes sub-stratified by ethnic origin, mothers in the 'inadequate'-diet group were randomly allocated to a supplemented group (group 2) or an unsupplemented group (group 3) (Fig. 1). The

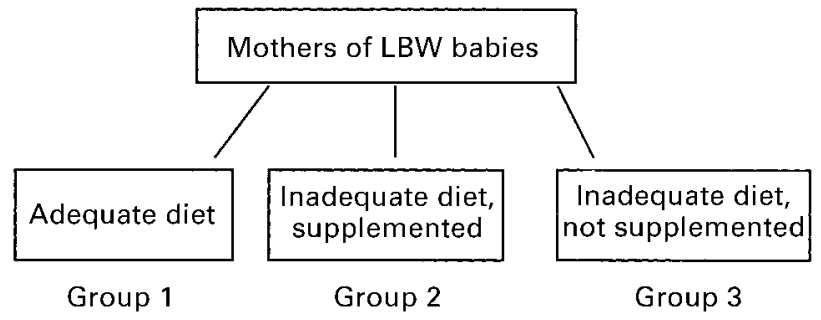

Fig. 1. Design of study.

supplement was provided free of charge to group 2. Assignment of women into groups 2 and 3 was enforced throughout the study regardless of recruits dropping out.

All mothers who completed a diary received a written report with dietary advice based on the information provided in the diary. Although a previous study (Doyle et al. 1999) had not proved successful in improving the diets of many women in this population, it was believed appropriate to provide mothers with this feedback if they had filled in a diary. They were also provided with general lifestyle advice on smoking, alcohol and drug use when preparing for pregnancy. In addition to the report, mothers in group 2 were provided with a multivitamin-mineral (Neovin; Numico Research, Wageningen, The Netherlands) and a docosahexaenoic acid supplement (DHASCO, Martek, Columbia, MD, USA) (Table 2). All mothers were contacted, on average, every 3 weeks to keep in touch, and to assess and encourage compliance with the supplemented group. At the end of the 6-month period (9 months post-partum) all women were invited to keep a second $7 \mathrm{~d}$ diary to assess changes in their diet.

Of 224 mothers who were eligible, only thirty-eight completed the study (Fig. 2). These constituted $31 \%$ of the eligible sample and $42 \%$ of mothers who agreed to participate. They included eleven in group 1, eleven in group 2 and sixteen in group 3. Of the seventeen mothers allocated to group 2, six dropped out because they did not

Table 1. Composition of supplements

\begin{tabular}{lc}
\hline & Per tablet \\
\hline NeoVin vitamin-mineral supplement* & 3 \\
$\beta$-Carotene $(\mathrm{mg})$ & $1 \cdot 6$ \\
Thiamin $(\mathrm{mg})$ & $1 \cdot 8$ \\
Riboflavin $(\mathrm{mg})$ & 20 \\
Niacin $(\mathrm{mg})$ & $2 \cdot 2$ \\
Pyridoxine $(\mathrm{mg})$ & 400 \\
Folic acid $(\mu \mathrm{g})$ & $2 \cdot 6$ \\
Vitamin $\mathrm{B}_{12}(\mu \mathrm{g})$ & 100 \\
Biotin $(\mu \mathrm{g})$ & 7 \\
Pantothenic acid (mg) & 12 \\
Vitamin C (mg) & 130 \\
Calcium $(\mathrm{mg})$ & 75 \\
Magnesium (mg) & 15 \\
Iron (mg) & 10 \\
Zinc (mg) & 100 \\
lodine $(\mu \mathrm{g})$ & 150 \\
Fish-oil capsule† & 8 \\
Docosahexaenoic acid $(\mathrm{mg})$ & \\
$\alpha$-Tocopherol acetate $(\mathrm{mg})$ & \\
\hline
\end{tabular}

* Numico Research, Wageningen, The Netherlands; one tablet/d.

† DHASCO, Martek, Columbia, MD, USA; two capsules/d. 
Table 2. Description of the thirty-eight mothers who completed the study

\begin{tabular}{lccc}
\hline & $\begin{array}{c}\text { Adequate-diet, } \\
\text { unsupplemented } \\
\text { (group 1, } n \text { 11) }\end{array}$ & $\begin{array}{c}\text { Inadequate-diet, } \\
\text { supplemented } \\
\text { (group 2, } n \text { 11) }\end{array}$ & $\begin{array}{c}\text { Inadequate-diet } \\
\text { unsupplemented } \\
\text { (group 3, } n \text { 16) }\end{array}$ \\
\hline Age (years) & $31 \cdot 0$ & & $28 \cdot 4$ \\
$\quad$ Mean & $30 \cdot 0$ & $30 \cdot 0$ & $28 \cdot 5$ \\
$\quad$ Median & 1 & $30 \cdot 0$ & 2 \\
Teenagers $(n)$ & $17-41$ & 0 & $16-43$ \\
Age range & & $21-38$ & \\
Ethnic origin $(n)$ & 7 & & 9 \\
$\quad$ Caucasian & 4 & 5 & 6 \\
Afro-Caribbean & 0 & 4 & 1 \\
Asian & 5 & 2 & 6 \\
Non-manual $(n)$ & 1 & 5 & 4 \\
Smokers $(n)$ & 5 & 3 & 10 \\
Preterm birth $(<37$ weeks) $(n)$ & 3 & 6 & 9 \\
Birth weight $<$ 10th centile $(n)$ & & 6 & \\
\hline
\end{tabular}

like the supplement (Fig. 2). The remaining mothers in the supplemented group reported that they took the supplement five or more days per week. Only two mothers, both in group 1, were breast-feeding at the time of recruitment to the study (3 months post-partum); both discontinued during the first 3 months of the study.

Mothers recruited to the study had a blood sample $(10 \mathrm{ml})$ taken at 3 months and 9 months post-partum. Full blood counts were measured on samples of EDTAstabilised whole blood using a Coulter STKS analyser (Beckman Coulter, High Wycombe, HP1 1JU, UK) on the day of collection. The EDTA sample was also used for erythrocyte folate analysis. Blood samples were centrifuged within $1 \mathrm{~h}$ of being taken and stored as subsamples at $-30^{\circ} \mathrm{C}$. Folate and ferritin were analysed using the IMx System (Abbots, Nordon Rd, Maidenhead, SL6 4XF), a fully automated immunoassay analyser. Serum ferritin was measured using microparticle enzyme immunoassay and erythrocyte and serum folate by ion capture technology. Blood samples were analysed at the Homerton Hospital where both analysers used were routinely subjected to quality assurance checks.

Erythrocyte folate concentrations $<230 \mathrm{nmol} / 1$ are considered to be severely deficient, while concentrations between $230 \mathrm{nmol} / 1$ and $345 \mathrm{nmol} / 1$ indicate marginal status (Sauberlich et al. 1974). The normal range for serum folate concentration is considered to be between $7 \mathrm{nmol} / \mathrm{l}$ and $46 \mathrm{nmol} / \mathrm{l}$ (Dacie \& Lewis, 1995). The WHO lower limit for normal haemoglobin concentration for women is $120 \mathrm{~g} / \mathrm{l}$ (World Health Organization, 1972); the normal range for serum ferritin concentration for women is considered to be $15-150 \mu \mathrm{g} / \mathrm{l}$ (Sauberlich et al. 1974).

The Statistical Package for the Social Sciences (1999; SPSS Inc, Chicago, IL, USA) was used to analyse the data. Statistical analysis included means, standard deviations, paired samples $t$ tests, the Mann-Whitney $U$ test, linear regression, and Fisher's exact test.

\section{Results \\ Sample}

Table 2 provides background information on mothers who completed the study. There were no statistically significant differences in the variables listed between the women who did and did not have an adequate diet. The age range was wide, with two teenage mothers in the inadequate-diet unsupplemented group and one in the adequate-diet group. There were similar proportions of manual workers among those who did and did not have an adequate diet in each group; disposable income was not recorded.
224 women delivered LBW baby

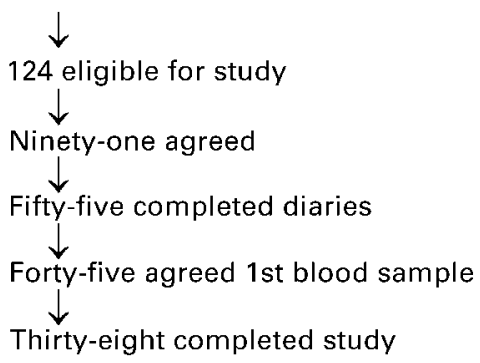

100 ineligible or had left hospital before being interviewed (twenty-six non-English speaking, twenty-two taking supplements nineteen had SB or NND, eight medical reasons, twenty-five discharged before being seen)

Thirty-three refused

Thirty-six did not complete a diary

Ten refused to have blood taken

Seven withdrew (six from supplemented group)

Fig. 2. Recruitment process of study. LBW, low birth weight; SB, stillbirth, NND, neonatal death. 
Table 3. Mean daily intakes of fifty-five mothers assessed to have 'adequate' or 'inadequate' diets at 3 months post-partum* (Mean values and standard deviations)

\begin{tabular}{|c|c|c|c|c|c|}
\hline & \multirow[b]{2}{*}{ DRV† } & \multicolumn{2}{|c|}{ 'Adequate' diet (group 1, $n$ 12) } & \multicolumn{2}{|c|}{ 'Inadequate' diet (groups 2 and $3, n 43$ ) } \\
\hline & & Mean & SD & Mean & SD \\
\hline Energy (kcal) & $1940-2110$ & 2263 & 465 & 1633 & 350 \\
\hline$(\mathrm{MJ})$ & $8 \cdot 83-8 \cdot 10$ & 9.49 & 1.94 & 6.84 & 1.46 \\
\hline Protein $(\mathrm{g})$ & $45 \cdot 0$ & $86 \cdot 4$ & $13 \cdot 3$ & $62 \cdot 1$ & $14 \cdot 0$ \\
\hline Fibre $(g)$ & $18 \cdot 0$ & $15 \cdot 8$ & 5.48 & $8 \cdot 16$ & 3.28 \\
\hline Calcium (mg) & $700-800$ & 1067 & 232 & 560 & 224 \\
\hline Iron (mg) & $14 \cdot 8$ & $15 \cdot 0$ & 2.93 & $9 \cdot 05$ & 2.42 \\
\hline Magnesium (mg) & $270-300$ & 319 & $43 \cdot 2$ & 187 & $50 \cdot 4$ \\
\hline Zinc (mg) & $7 \cdot 0$ & $10 \cdot 3$ & $2 \cdot 61$ & $7 \cdot 31$ & 2.05 \\
\hline Selenium $(\mu \mathrm{g})$ & $60 \cdot 0$ & $68 \cdot 2$ & $19 \cdot 2$ & 39.9 & $15 \cdot 8$ \\
\hline lodine $(\mu \mathrm{g})$ & 140 & 141 & $32 \cdot 9$ & $78 \cdot 0$ & $45 \cdot 6$ \\
\hline Vitamin A $(\mu \mathrm{g})$ & 600 & 1004 & 399 & 753 & 1021 \\
\hline Thiamin (mg) & 0.8 & 1.67 & 0.25 & 1.00 & 0.43 \\
\hline Riboflavin (mg) & $1 \cdot 1$ & $2 \cdot 00$ & 0.52 & 1.02 & 0.41 \\
\hline Niacin equivalents (mg) & $13 \cdot 0$ & 39.9 & $5 \cdot 67$ & $27 \cdot 1$ & $6 \cdot 91$ \\
\hline Vitamin $B_{6}(\mathrm{mg})$ & $1 \cdot 2$ & $2 \cdot 43$ & 0.51 & 1.37 & 0.44 \\
\hline Vitamin $B_{12}(\mu \mathrm{g})$ & 1.5 & $6 \cdot 30$ & 3.07 & 4.17 & 3.98 \\
\hline Folate $(\mu \mathrm{g})$ & $200 \ddagger$ & 331 & $91 \cdot 0$ & 162 & $61 \cdot 6$ \\
\hline Vitamin C (mg) & $40 \cdot 0$ & 121 & $73 \cdot 0$ & 53.4 & 35.4 \\
\hline
\end{tabular}

* For details of subjects and procedures, see Table 2 and p. 82 .

† DRV, dietary reference values for non-pregnant women of childbearing age (Department of Health, 1991)

$\ddagger$ The Department of Health has recommended all women should increase their folate-folic acid intake by $400 \mu \mathrm{g} / \mathrm{d}$ prior to conception and during the first 12 weeks of pregnancy (Department of Health, 1992).

\section{Dietary intakes}

Of the mothers ( $n$ 55) who agreed to participate, $60 \%$ completed dietary assessments (Fig. 2). The main reason provided by the mothers for not completing the diary was lack of time. Seventy-eight percent of the mothers met fewer than four of the sixteen dietary reference values and were therefore considered to have an inadequate diet. Mothers whose diets were assessed as inadequate were younger than those in the adequate-diet group $(P<0.05)$, but there was no significant difference in the proportion of ethnic minorities, cigarette smokers and non-smokers, nonmanual occupations and manual or unemployed, or marital status, in the adequate- and inadequate-diet groups.

Table 3 shows a comparison of the mean intakes of mothers whose diets were assessed as being adequate or inadequate. There were significant differences between the intake of energy and all nutrients in Table $3(P<0.001$, except $\mathrm{Zn} P=0.001$, vitamin $\mathrm{B}_{12} P=0.002$, and vitamin A $P=0.005)$.
Only nine of the thirty-eight mothers kept a second diary at 9 months post-partum, three mothers assessed initially as having an adequate diet (group 1) and six mothers assessed as having an inadequate diet (one in group 2 and five in group 3). None of the mothers had significantly changed their energy or nutrient intakes from food sources.

\section{Folate and iron status 3 months post-partum}

At 3 months post-partum, mothers assessed as having an inadequate diet had a significantly lower mean serum folate level $(P<0.005)$ than those with an adequate diet (Table $4)$. Over $60 \%$ of the former and $27 \%$ of the latter group had serum folate levels $<7 \mathrm{nmol} / \mathrm{l}$, the lower level of the normal range.

A high proportion of mothers (56\%) assessed as having inadequate diets also had erythrocyte folate concentrations $<230 \mathrm{nmol} / \mathrm{l}$ indicating severe deficiency, while a further

Table 4. Haemoglobin, serum ferritin, serum folate and erythrocyte folate concentrations 3 months post-partum of thiry-eight mothers whose dietary intakes were assessed as being 'adequate' or 'inadequate"*

(Mean values and standard deviations)

\begin{tabular}{|c|c|c|c|c|c|c|c|}
\hline & \multirow[b]{2}{*}{ Normal range } & \multicolumn{3}{|c|}{ 'Adequate' diet ( $n$ 11) } & \multicolumn{3}{|c|}{ 'Inadequate' diet (n 27) } \\
\hline & & Mean & SD & Below normal range $(n)$ & Mean & SD & Below normal range $(n)$ \\
\hline Serum folate $(\mathrm{nmol} / \mathrm{l})$ & $7-46 \dagger$ & $9 \cdot 06 \ddagger$ & 3.29 & 3 & 6.09 & $2 \cdot 15$ & 17 \\
\hline Erythrocyte folate $(\mathrm{nmol} / \mathrm{l})$ & $230 \S$ & 265 & 58.5 & 3 & 227 & 74.5 & 15 \\
\hline Serum ferritin $(\mu \mathrm{g} / \mathrm{l})$ & $15-150 \S$ & $31 \cdot 3$ & $29 \cdot 8$ & 5 & $25 \cdot 6$ & $32 \cdot 1$ & 14 \\
\hline Haemoglobin $(\mathrm{g} / \mathrm{l})$ & $120-165 \|$ & 128 & $10 \cdot 0$ & 1 & 128 & 8.4 & 5 \\
\hline
\end{tabular}

* For details of subjects and procedures, see Table 2 and p. 82.

$\dagger$ Dacie \& Lewis (1995).

$\ddagger P<0.05$ (Mann-Whitney two-tailed $U$ test)

$\S$ Sauberlich et al. (1974); severe folate deficiency at $<230 \mathrm{nmol} / \mathrm{l}$.

I| World Health Organization (1972). 
$37 \%$ had marginal status, with concentrations between 230 and $345 \mathrm{nmol} / \mathrm{l}$.

Regression analysis between measures of folate status and folate intake showed a significant positive relationship with serum folate $\left(P=0.016, r^{2} 0.164\right)$ but not with erythrocyte folate which reflects longer-term status.

Six out of thirty-eight mothers (16\%) in the study were found to be anaemic $(<120 \mathrm{~g}$ haemoglobin/l) at the beginning of the study, five of whom were in the inadequate-diet group.

Of all participants, $50 \%$ had serum ferritin levels $<15 \mu \mathrm{g} / \mathrm{l}$, indicating low $\mathrm{Fe}$ stores. No association was found between calculated $\mathrm{Fe}$ intake and measures of $\mathrm{Fe}$ status. However, regression analysis showed a significant positive relationship between serum ferritin and vitamin $\mathrm{C}$ intake $\left(P<0.001, r^{2} 0 \cdot 345\right)$, an enhancer of non-haem $\mathrm{Fe}$ absorption.

\section{Changes in folate and iron status between 3 and 9 months post-partum}

Mean serum folate, erythrocyte folate and serum ferritin levels increased significantly during the study period in women in the supplemented group (group 2), as did erythrocyte folate in the adequate-diet group (group 1), but there were no significant increases in Fe or folate levels in women with poor dietary intakes who did not receive a supplement (group 3) (Table 5). The proportion of mothers with low or marginal erythrocyte folate status fell dramatically in group 1 and group 2 while over half
(56\%) of group 3 remained below $230 \mathrm{nmol} / \mathrm{l}$ and a further $32 \%$ below $345 \mathrm{nmol} / \mathrm{l}$.

Serum ferritin levels of two mothers in the supplemented group $(18 \%)$ remained $<15 \mu \mathrm{g} / \mathrm{l}$ at 9 months post-partum compared with four $(36 \%)$ mothers in the adequate-diet group, and nine (56\%) mothers in unsupplemented, inadequate-diet group. Overall, the mean haemoglobin levels did not change significantly in any group.

\section{Discussion}

Unfavourable pregnancy outcomes, including low birth weight and preterm delivery, have been associated with short birth-intervals (Miller, 1989; Rawlings et al. 1995; Bao-Ping et al. 1999). Bao-Ping et al. (1999) reported that infants conceived 18-23 months after a previous live birth had the lowest risks of adverse outcomes including low birth weight, preterm birth and small size for gestational age. Klerman et al. (1998), in a study of a low-income population, found that the percentage of preterm births increased as the inter-pregnancy interval decreased.

The mechanism of the adverse effects of short pregnancy intervals has not been established, but the leading theory involves the incomplete restoration of the mother's physiologically critical nutrient reserves that are depleted during the course of pregnancy (Khan et al. 1998).

The present study confirmed our previous observation that mothers of low birth weight babies in this population are not receptive to a nutrition counselling programme designed to improve the nutritional status of mothers assessed as having an inadequate diet (Doyle et al. 1999).

Table 5. Serum and erythrocyte folate, serum ferritin and haemoglobin levels of mothers, no. below normal range at 3 and 9 months post-partum, and significance of difference at 9 months post-partum, by treatment group*

(Mean values and standard deviations)

\begin{tabular}{|c|c|c|c|c|c|c|c|c|c|c|c|c|}
\hline & \multicolumn{4}{|c|}{$\begin{array}{l}\text { 'Adequate' diet, } \\
\text { unsupplemented(group 1, } n \text { 11) }\end{array}$} & \multicolumn{4}{|c|}{$\begin{array}{c}\text { 'Inadequate' diet, } \\
\text { supplemented (group } 2, n \text { 11) }\end{array}$} & \multicolumn{4}{|c|}{$\begin{array}{l}\text { 'Inadequate' diet, } \\
\text { unsupplemented (group } 3, n \text { 16) }\end{array}$} \\
\hline & \multicolumn{2}{|c|}{3 months } & \multicolumn{2}{|c|}{9 months } & \multicolumn{2}{|c|}{3 months } & \multicolumn{2}{|c|}{9 months } & \multicolumn{2}{|c|}{3 months } & \multicolumn{2}{|c|}{9 months } \\
\hline & Mean & SD & Mean & SD & Mean & SD & Mean & SD & Mean & SD & Mean & SD \\
\hline $\begin{array}{l}\text { Serum folate }(\mathrm{nmol} / \mathrm{l}) \\
\text { Erythrocyte folate }(\mathrm{nmol} / \mathrm{l}) \\
\text { Serum ferritin }(\mu \mathrm{g} / \mathrm{l}) \\
\text { Haemoglobin }(\mathrm{g} / \mathrm{l})\end{array}$ & $\begin{array}{l}9 \cdot 06 \\
265 \\
31 \cdot 3 \\
128\end{array}$ & $\begin{array}{l}3 \cdot 29 \\
58 \cdot 4 \\
29 \cdot 8 \\
8 \cdot 4\end{array}$ & $\begin{array}{l}10 \cdot 5 \\
454^{\star *} \\
32 \cdot 6 \\
130\end{array}$ & $\begin{array}{l}3 \cdot 67 \\
190 \\
36 \cdot 4 \\
9 \cdot 6\end{array}$ & $\begin{array}{l}6 \cdot 74 \\
227 \\
25 \cdot 5 \\
128\end{array}$ & $\begin{array}{l}2 \cdot 52 \\
86 \cdot 8 \\
30 \cdot 1 \\
7 \cdot 4\end{array}$ & $\begin{array}{l}12 \cdot 5^{\star \star \star} \\
346^{\star \star \star} \\
36 \cdot 0^{\star \star} \\
126\end{array}$ & $\begin{array}{l}3.34 \\
91 \cdot 3 \\
27 \cdot 3 \\
8 \cdot 4\end{array}$ & $\begin{array}{c}5 \cdot 64 \\
226 \\
25 \cdot 7 \\
127\end{array}$ & $\begin{array}{l}1 \cdot 80 \\
67 \cdot 8 \\
34 \cdot 3 \\
11 \cdot 7\end{array}$ & $\begin{array}{c}5 \cdot 57 \\
255 \\
25 \cdot 4 \\
131\end{array}$ & $\begin{array}{c}0.99 \\
98.2 \\
29.5 \\
8.8\end{array}$ \\
\hline $\begin{array}{l}\text { Below normal range }(n) \\
\text { Serum folate }<7 \mathrm{nmol} / / \dagger \\
\text { Erythrocyte folate }<230 \mathrm{nmol} / / \ddagger \\
\text { Erythrocyte folate }<345 \mathrm{nmol} / / \ddagger \\
\text { Serum ferritin }<15 \mu \mathrm{g} / 1 \ddagger \\
\text { Haemoglobin }<12 \mathrm{~g} / \S\end{array}$ & $\begin{array}{r}3 \\
3 \\
11 \\
5 \\
1\end{array}$ & $\begin{array}{l}3 \\
3 \\
1 \\
5\end{array}$ & & $\begin{array}{l}2 \\
1 \\
4 \\
4 \\
2\end{array}$ & $\begin{array}{r}7 \\
7 \\
10 \\
5 \\
1\end{array}$ & $\begin{array}{l}7 \\
5 \\
5 \\
1\end{array}$ & $\begin{array}{l}1 \\
1 \\
4 \\
2 \\
2\end{array}$ & & $\begin{array}{r}10 \\
8 \\
15 \\
9 \\
4\end{array}$ & & 1 & $\begin{array}{l}+ \\
y\end{array}$ \\
\hline $\begin{array}{l}\text { Significance of difference between } \\
\text { Groups: } \\
\text { Serum folate } \\
\text { Erythrocyte folate } \\
\text { Serum ferritin } \\
\text { Haemoglobin }\end{array}$ & groups at & 9 mont 1 ar & $\begin{array}{l}\text { is post-p } \\
\text { d } 2\end{array}$ & artum (N & lann-Whitr & $\begin{array}{r}\text { ney } 2 \text {-ta } \\
2 \text { a } \\
<0 \\
0 \\
0\end{array}$ & $\begin{array}{l}\text { iled U test } \\
\text { nd } 3 \\
.001 \\
.009 \\
.034 \\
-\end{array}$ & t): $P$ & & $\begin{array}{r}1 \mathrm{a} \\
<0 \\
0\end{array}$ & $\begin{array}{l}\text { Id } 3 \\
001 \\
001\end{array}$ & \\
\hline
\end{tabular}

${ }^{*}$ For details of subjects and procedures, see Table 2 and p. 82.

† Dacie \& Lewis (1995)

¥ Sauberlich et al. (1974); 230-345 nmol/l indicates marginal status.

$\S$ World Health Organization (1972).

Mean values were significantly different from values at 3 months post-partum (paired samples $t$ test): ${ }^{\star \star} P<0 \cdot 01$, ${ }^{\star \star \star} P<0 \cdot 001$. 
In that nutrition counselling study, seventy-seven of 111 eligible mothers participated. Of these, the calculated micronutrient intake of seventy was arbitrarily defined as 'inadequate', meeting fewer than four of sixteen dietary reference values (Department of Health, 1991); forty-one of the seventy mothers completed the 6-month counselling programme satisfactorily. The fact that only fifty-five of 124 eligible women in the present study completed even the first diet diary is indicative of the difficulties. This was a heterogeneous group of mothers, some of whose babies were small but well, while others had acute medical problems, such as hypoglycaemia and suspected early neonatal infections requiring medical intervention. The reasons for the lack of efficacy of counselling are unclear, but one perception which requires study is that many women do not recognise the birth of a small but well baby as a problem. However, the findings of other nutrition intervention studies during pregnancy failed to show any clear relationship between nutritional knowledge, attitude and behaviour, reporting improvements in nutrition knowledge, but this did not lead to significant improvements in nutrient intake (Anderson et al. 1995; Belizán et al. 1995). In a systematic review of effectiveness of interventions to promote healthy eating in pregnant women and women of childbearing age, van Teijlingen et al. (1998) suggested that it was not possible to conclude whether or not healthyeating interventions are effective, even during pregnancy. Clearly more inter-disciplinary research is required into effective methods of improving nutritional intakes of socially disadvantaged populations.

The method of dietary assessment and allocation of mothers to an inadequate diet on the basis of meeting fewer than four dietary reference values (Department of Health, 1991) was effective in differentiating between the adequate and inadequate groups as evidenced by the observed improvement in the folate and Fe status of the unsupplemented, adequate-diet group, while the unsupplemented, inadequate-diet group did not improve. However, women were reluctant to complete a diet diary as shown by the loss of recruits at that stage of the study (see Fig. 2). Further, the dietary analysis requires specialist knowledge and the technique would not be practicable as a routine clinical tool.

The incidence of folate deficiency was higher (47\% of all mothers at 3 months post-partum) than reported by Chanarin (1979) who found that $25 \%$ of women suffered from severe folic acid deficiency at the end of pregnancy. Despite the number of women completing the study being low, it was observed that women in the adequate-diet group spontaneously improved their folate status. In contrast, in the unsupplemented, inadequate-diet group, the number of women with low folate levels increased during the study period. From their reported diet diaries, mothers in the adequate-diet group were more than twice as likely to consume breakfast cereals fortified with folate and in some cases, Fe, than those in the inadequate-diet groups. Consumption of fortified breakfast cereals should be encouraged in all mothers throughout the reproductive cycle, including post-partum.

Low ferritin levels were common across all groups at 3 months post-partum, but particularly in the unsupplemented, inadequate-diet group. The failure to improve serum ferritin levels supports the findings of Taylor et al. (1982) who reported that, in the absence of supplementation, it appears to take up to 2 years for a mother to replenish her Fe stores after pregnancy. No other published work on supplementation in the inter-pregnancy interval was identified.

Dietary supplementation of women with inadequate diets with vitamins and minerals was partially effective, but the results would suggest that at this dosage (Table 1), a longer period is required to restore levels to the normal range. This study confirms the practical difficulty in this population of detailed dietary assessment to select women for supplementation. The supplement dosage used in this study would not have adverse effects if taken by women with an adequate diet and consideration should be given to recommending routine folate and $\mathrm{Fe}$ supplementation to all women from this and similar populations, or at least to women who have had a small baby and who plan further pregnancies.

\section{Acknowledgements}

This study has received financial support from the Joint Research Board of St Bartholomew's Hospital, The Mother and Child Foundation and Nutricia Ltd, UK \& Numico Research, The Netherlands. We thank the participants for their support in this study. We would also like to acknowledge the support of the late Dr Anne Gibson MD, FRCPath.

\section{References}

Anderson AS, Campbell DM \& Shepherd R (1995) The influence of dietary advice on nutrient intake during pregnancy. British Journal of Nutrition 73, 163-177.

Bao-Ping Z, Rolfs RT, Nangle BE \& Horan JM (1999) Effect of the interval between pregnancies on perinatal outcomes. New England Journal of Medicine 340, 589-594.

Belizán JM, Barros F \& Langer A (1995) Impact of health education during pregnancy on behaviour and utilisation of health resources. American Journal of Obstetrics and Gynecology 173, 894-899.

Blonk MC, Bilo HJG, Nauta JJ, Popp-Snijders C, Mulder C \& Donker AJ (1990) Dose-response effects of fish-oil supplementation in healthy volunteers. American Journal of Clinical Nutrition 52, 120-127.

Chanarin I (1979) Distribution of folate deficiency. In Folic Acid in Neurology, Psychiatry and Internal Medicine [MI Botez and EH Reynolds, editors]. New York, NY: Raven.

Cuskelly GJ, McNulty H \& Scott JM (1996) Effect of increasing dietary folate on red cell folate: implications for prevention of neural tube defects. Lancet 347, 657-659.

Czeizel AE (1993) Prevention of congenital abnormalities by periconceptional multivitamin supplementation. British Medical Journal 306, 1645-1648.

Dacie JV \& Lewis SM (1995) Practical Haematology, 8th ed. Edinburgh: Churchill Livingstone.

Department of Health (1991) Dietary Reference Values for Food Energy and Nutrients for the United Kingdom. Report on Health and Social Subjects no. 41. London: H.M. Stationery Office.

Department of Health (1992) Folic Acid and the Prevention of 
Neural Tube Defects. Report from an Expert Advisory Group. Lancashire: Health Publications Unit.

Doyle W, Crawford MA, Strivastava A \& Costeloe KL (1999) Interpregnancy nutrition intervention with mothers of low birthweight babies living in an inner city area - a feasibility study. Journal of Human Nutrition and Dietetics 12, 517-528.

Doyle W, Crawford MA, Wynn AHA \& Wynn SW (1990) The association between maternal diet and birth dimensions. Journal of Nutritional Medicine 1, 9-17.

Doyle W, Jenkins S, Crawford MA \& Puvandendran K (1994) The nutritional status of school children in an inner city area. Archives of Disease in Childhood 70, 376-381.

Khan KS, Chien PF \& Khan NB (1998) Nutritional stress of reproduction. A cohort study over two consecutive pregnancies. Acta Obstetricia et Gynecologica Scandinavica 77, 395-401.

Klerman LV, Cliver SP \& Goldenberg RL (1998) The impact of short inter-pregnancy outcomes in a low income population. American Journal of Public Health 88, 1182-1185.

Miller JE (1989) Determinants of intrauterine growth retardation: evidence against maternal deprivation. Journal of Biosocial Science 21, 235-243.

Office of National Statistics (1998) Monitor Population and Health: Infant and Perinatal Mortality 1997. Series DH3 98/1. London: Office of National Statistics.

Paul AA \& Southgate DAT (1991) McCance and Widdowson's The Composition of Foods, 5th ed. London: Ministry of Agriculture, Fisheries and Food.

Raine T, Powell S \& Krohn MA (1994) The risk of repeating low birth weight and the role of prenatal care. Obstetrics and Gynecology 84, 485-489.

Rawlings JS, Rawlings VB \& Read JA (1995) Prevalence of low birthweight and preterm delivery in relation to the interval between pregnancies among white and black women. New England Journal of Medicine 332, 69-74.

Sauberlich HE, Skala JH \& Dowdy RP (1974) Laboratory Tests for the Assessment of Nutritional Status, pp. 49-60. Cleveland, $\mathrm{OH}$ : CRC Press.

Scholl TO, Hediger ML, Bendich A, Scholl JI, Woolcott KS \& Kruger PM (1997) Use of prenatal supplements: influence on the outcome of pregnancy. American Journal of Epidemiology 146, 134-141.

Shaw GM \& Lammer EJ (1995) Risks of orofacial clefts in children born to women using multivitamins containing folic acid periconceptionally. Lancet 346, 393-396.

Taylor DJ, Mallen C, McDougall N \& Lind T (1982) Serum ferritin in women of reproductive age. British Journal of Obstetrics and Gynaecology 89, 1000-1005.

van Teijlingen ER, Wilson BJ, Barry A, McNeill G, Graham W \& Cambell D (1998) Effectiveness of Interventions to Promote Healthy Eating in Pregnant Women and Women of Childbearing Age: A Review. London: Health Education Authority.

Wald N, Sneddon J, Densem J, Frost C \& Stone R (1991) Prevention of neural tube defects: results of the Medical Research Council vitamin study. Lancet 338, 131-137.

World Health Organization (1972) Nutritional Anaemias. Technical Report Series no. 503. Geneva: WHO. 